\title{
Recent Improvement in Particulate Matter (PM) Pollution in Ulaanbaatar, Mongolia
}

\author{
Gantuya Ganbat ${ }^{1}$, Tseren-Ochir Soyol-Erdene ${ }^{2 *}$, Batbayar Jadamba ${ }^{3}$ \\ ${ }^{1}$ National Committee on Reducing Environmental Pollution, Ministry of Environment and Tourism, Ulaanbaatar 15160, \\ Mongolia \\ ${ }^{2}$ Department of Environmental and Forest Engineering, School of Engineering and Applied Sciences, National University \\ of Mongolia, Ulaanbaatar 14201, Mongolia \\ ${ }^{3}$ National Agency for Meteorology and Environmental Monitoring, Ministry of Environment and Tourism, Ulaanbaatar \\ 15160, Mongolia
}

\begin{abstract}
Ulaanbaatar, the capital city of Mongolia, has occasionally been considered the most polluted city in the world. Approximately $46 \%$ of the population resides in Ulaanbaatar, and over half of the population living in ger (traditional yurt dwelling) areas consumes raw coal, which leads to an increase in ambient air pollutants. The Government of Mongolia took a series of actions to reduce air pollution; one was the ban on the consumption of raw coal beginning on 15 May 2019 . In this study, improvement in particulate matter (PM) air quality was shortly studied by assessing the hourly data for the last six years, from January 2014 to February 2020. The analysis exhibited a major improvement in PM concentrations during the 2019-2020 winter in Ulaanbaatar. The average PM concentrations clearly exhibited a decreasing trend in November 2019-February 2020 compared to the previous five years. The maximum $\mathrm{PM}_{2.5}$ and $\mathrm{PM}_{10}$ concentrations were reduced to $46 \%$ and $55 \%$, respectively, compared to the mean maximum values of the previous five years. The most prominent occurrence frequency of PM concentrations shifted to a lower concentration range. Although a PM pollution reduction was seen during the 2019-2020 winter, further air quality improvement can be obtained by taking a set of multiple actions with accurate planning management.
\end{abstract}

Keywords: Particulate matter; Improvement in air quality; Reductions in PM concentrations; Ulaanbaatar; Mongolia.

\section{INTRODUCTION}

Ulaanbaatar, the capital city of Mongolia, is situated in a dome valley located at a high altitude of $\sim 1300 \mathrm{~m}$ above sea level and is far from any coast. Due to its location, Ulaanbaatar is known as the coldest capital in the World. It is a home of over 1.5 million people which is around $46 \%$ of the population (Mongolian Statistical Information Service, 2020). Sixty percent of its population resides in ger areas which usually consumes raw coal and wood for heating and cooking purposes in the cold season. Pollutants are emitted from various sources including over 200,000 ger households, mainly using small stoves, 3000 heat-only boilers (HOBs), 4 power plants, over 500 thousand vehicles, and other sources. Based on the analysis of pollutants in PM collected

\footnotetext{
* Corresponding author.

Tel.: +976-77307730(3208); Fax: +976-11315631

E-mail address: soyolerdene@seas.num.edu.mn
}

for 2004-2008 in Ulaanbaatar, coal combustion processes are largely responsible for fine particle air pollution during winter. Major sources of coarse particle air pollution are crustal matter and coal combustion (Davy et al., 2011). In addition to the pollutant emission sources, the weather condition with temperature inversions under the Siberian high-pressure system (Ganbat and Baik, 2016) plays important role in air pollution in winter. Wintertime air pollution in Ulaanbaatar has been widely noted during the past $~ 15$ years (Guttikunda, 2007; Guttikunda et al., 2013; Ganbat and Baik, 2016).

For years, air pollution was a severe problem in winter, reaching values many times higher than the recommendations of the World Health Organization (WHO) guidelines. For instance, during December 2009-February 2010, the mean $\mathrm{PM}_{2.5}$ concentration was $171 \mu \mathrm{g} \mathrm{m}^{-3}$, with a maximum $24-\mathrm{h}$ value reaching $766 \mu \mathrm{g} \mathrm{m}^{-3}$ in Ulaanbaatar (Wang et al., 2018) which was 3.4 and 6.8 times higher than the 24-h average national air pollution standard level of $\mathrm{PM}_{2.5}$ according to the National Air Quality Standard MNS 4585:2016 of Mongolia (50 $\mathrm{g} \mathrm{m}^{-3}$ for the 24 -h average) and WHO guideline level 
(25 $\mathrm{g} \mathrm{g} \mathrm{m}^{-3}$ for the 24-h average), respectively. Long-time high PM concentrations present in wintertime in Ulaanbaatar are likely to have negative effects on the health of the exposed population. According to a study by Enkhjargal and Burmaajav (Enkhjargal and Burmaajav, 2015), hospitalization for cardiovascular disease increases by $0.65 \%$ on a day of exposure with $100 \mu \mathrm{g} \mathrm{m}^{-3}$ growth of $\mathrm{PM}_{2.5}$ concentration. Additionally, it was shown that air pollution and decreased fetal wellbeing were strongly correlated (Enkhmaa et al., 2014).

The government of Mongolia put tremendous effort and sources to combat air pollution in Ulaanbaatar; for example, during 2008-2016, 164.1 billion MNT and 104.7 million USD were spent on actions to reduce air pollution (National Audit report, 2018). One of the most recent actions is banning the consumption of raw coal, the combustion of which in small stoves is a primary source of air pollution, and replacing it with high-quality briquette fuel. Starting on 15 May 2019, the consumption of raw coal was banned for household consumption in Ulaanbaatar according to the Governmental decision. Air quality improvement is expected as a result of the coal-replacement program on briquette fuel substitution.

PM concentration reductions are reported in monthly reports released by the National Agency for Meteorology and Environmental Monitoring (NAMEM) (www.agaar.mn). The monthly average concentrations of $\mathrm{PM}_{2.5}$ and $\mathrm{PM}_{10}$ for October-February of 2018-2019 and 2019-2020 (i.e., winters), which represent up to 50\% PM reductions from the previous year are presented in Table 1.

The aim of this study is to describe the improvement in PM pollution in Ulaanbaatar evidenced during winter 20192020. This study does not estimate the effects of weather conditions on air quality or the economic benefits and health benefits of air quality. According to reports released from the NAMEM, there was no notable exceptional weather condition during the 2019-2020 winter (www.tsag-agaar.mn).

\section{STUDY AREA AND DATA}

Fig. 1 shows the location of Ulaanbaatar, Mongolia and 12 air quality monitoring sites in Ulaanbaatar which are operated by the NAMEM and the Agency Against Air Pollution (AAAP) of the Municipality. Up to six pollutants$\mathrm{PM}_{2.5}, \mathrm{PM}_{10}, \mathrm{SO}_{2}, \mathrm{NO}_{2}, \mathrm{CO}, \mathrm{O}_{3}$ - are measured at the sites, though not all sites measured all six pollutants. $\mathrm{PM}_{10}$ is measured at twelve sites, while $\mathrm{PM}_{2.5}$ is measured at eight sites (Table 2). In this study, we analyzed the hourly mean $\mathrm{PM}_{2.5}$ and $\mathrm{PM}_{10}$ concentrations for the period from 01
January 2014 to 29 February 2020, which were obtained from 12 air quality monitoring sites (Fig. 1).

The current national air quality standard, a maximum permissible level of pollutants in the air and physical negative impacts were amended in 2016. The national standard levels of air pollutants are $50 \mu \mathrm{g} \mathrm{m}^{-3}$ and $100 \mu \mathrm{g} \mathrm{m}^{-3}$ for $24-\mathrm{h} \mathrm{PM}_{2.5}$ and $\mathrm{PM}_{10}$, respectively. The annual standard levels were set $25 \mu \mathrm{g} \mathrm{m}^{-3}$ and $50 \mu \mathrm{g} \mathrm{m}^{-3}$ for $\mathrm{PM}_{2.5}$ and $\mathrm{PM}_{10}$, respectively.

\section{AIR POLLUTION REDUCTION MEASURES: A BAN ON RAW COAL CONSUMPTION}

In recent years, the air pollution problem in Ulaanbaatar has tended to worsen, which is directly related to raw coal consumption. To address this challenge, beginning 15 May 2019 , the consumption of raw coal in six central districts in Ulaanbaatar has been replaced by the consumption of briquette fuel for the improvement of air quality according to Governmental Resolution No. 62 adopted in 2018. The briquette fuel factory 'Tavan Tolgoi Tulsh' with an annual output capacity of 600,000 tons made by refined energy coal from the Ukhaa Khudag coal mine, was established in Ulaanbaatar in 2018. The refined energy coal is considered as high-grade coal with approximately two times the calorific value $(\geq 4200 \mathrm{kCal})$, less moisture content $(\leq 10 \%)$, and low volatile matter $(\leq 29 \%)$ than the previously- and frequently-used raw coal in Ulaanbaatar, and it fully satisfies the National Standard-Refined solid fuel, MNS 5679:2019. The factory has started supplying briquette coal to households in Ulaanbaatar since the autumn 2019.

In addition to banning the consumption of raw coal, the Government enables other actions, including subsidies for the installation of energy-efficient technologies for HOBs and HOB chimney scrubbers, as well as public awareness regarding various actions, such as raw coal control and consumption instructions of briquette fuel. In addition, volunteers participated in collecting "survey on living environment" data in ger areas using a smartphone application, which is considered the largest collection of households' information living in ger areas of Ulaanbaatar.

\section{GENERAL CHARACTERISTICS OF TEMPORAL VARIATIONS IN PM CONCENTRATIONS IN ULAANBAATAR}

The intent of this section is to provide an overview of PM pollutant characteristics in Ulaanbaatar.

Table 1. Monthly mean $\mathrm{PM}_{2.5}$ and $\mathrm{PM}_{10}$ concentrations for October 2018-February 2019 and October 2019-February 2020 (winters) averaged over the air quality monitoring sites in Ulaanbaatar and their reduction load. (source: www.agaar.mn)

\begin{tabular}{|c|c|c|c|c|c|c|}
\hline Components & \multicolumn{3}{|c|}{$\mathrm{PM}_{2.5}$} & \multicolumn{3}{|c|}{$\mathrm{PM}_{10}$} \\
\hline Month & 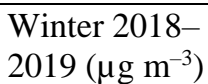 & $\begin{array}{l}\text { Winter 2019- } \\
2020\left({\left.\mu \mathrm{g} \mathrm{m}^{-3}\right)}^{2}\right.\end{array}$ & $\begin{array}{l}\text { Reduction } \\
\text { load, \% }\end{array}$ & $\begin{array}{l}\text { Winter } 2018- \\
2019\left(\mu \mathrm{g} \mathrm{m}^{-3}\right)\end{array}$ & $\begin{array}{l}\text { Winter 2019- } \\
2020\left({\left.\mu \mathrm{g} \mathrm{m}^{-3}\right)}^{2}\right.\end{array}$ & $\begin{array}{l}\text { Reduction } \\
\text { load, \% }\end{array}$ \\
\hline October & 48 & 39 & -19 & 127 & 127 & 0 \\
\hline November & 108 & 61 & -43 & 208 & 121 & -42 \\
\hline December & 182 & 113 & -38 & 242 & 138 & -43 \\
\hline January & 195 & 104 & -47 & 249 & 129 & -48 \\
\hline February & 120 & 68 & -43 & 194 & 97 & -50 \\
\hline
\end{tabular}


(a)

(b)
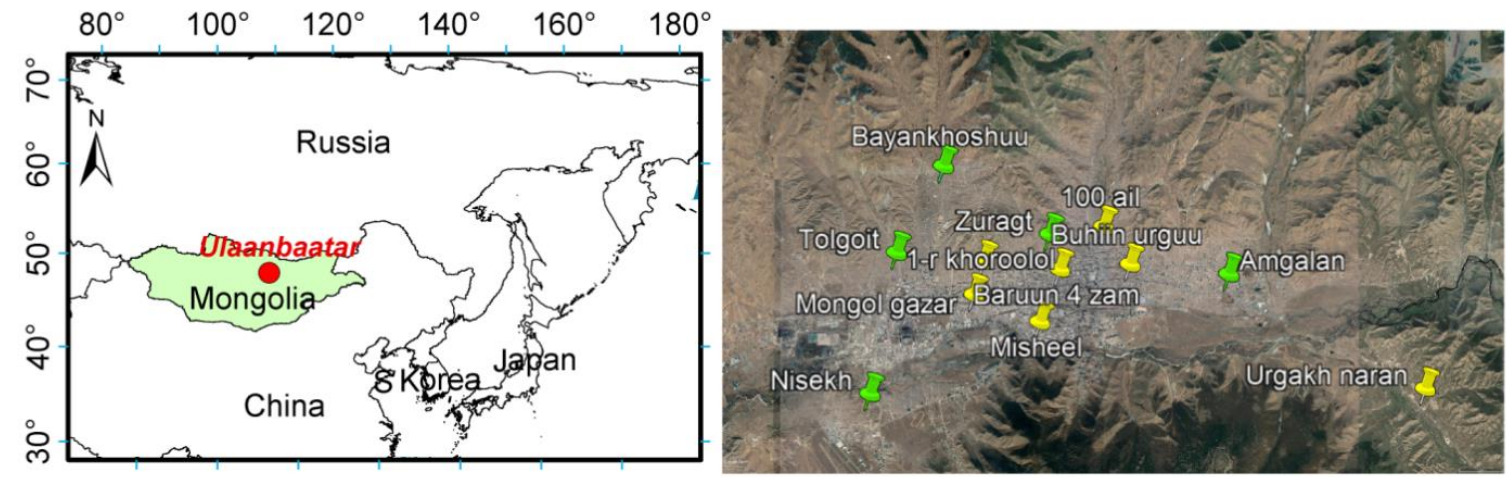

Fig. 1. (a) Location of Ulaanbaatar, Mongolia. (b) Air quality monitoring sites in Ulaanbaatar. Yellow (green) marks indicate the sites operated by the NAMEM (AAAP).

Table 2. Air quality monitoring sites in Ulaanbaatar, their location classification, and monitor devices.

\begin{tabular}{llll}
\hline Site name, ID & Location & $\mathrm{PM}_{10}$ & $\mathrm{PM}_{2.5}$ \\
\hline Misheel, UB1 & Industrial & + & - \\
Baruun 4 zam, UB2 & Traffic & + & + \\
1-r horoolol, UB3 & Ger area & + & + \\
Buhiin urguu, UB4 & Residential & + & + \\
100 ail, UB5 & Ger area & + & - \\
Mongol gazar, UB7 & Industrial & + & - \\
Urgakh naran, UB8 & Remote & + & - \\
Tolgoit, APRD1 & Ger area & + & + \\
Zuragt, APRD2 & Ger area & + & + \\
Amgalan, APRD3 & Traffic & + & + \\
Nisekh, APRD4 & Ger area & + & + \\
Bayankhoshuu, APRD6 & Ger area & + & + \\
\hline
\end{tabular}

Fig. 2 shows the time series of the daily mean $\mathrm{PM}_{2.5}$ and $\mathrm{PM}_{10}$ concentrations and temperature for the study period. The concentrations are averaged over the air quality monitoring sites, while the temperature is taken from the Ulaanbaatar station (44292). The annual mean $\mathrm{PM}_{2.5}\left(\mathrm{PM}_{10}\right)$ concentrations ranged from $50.0 \pm 46.8(106.3 \pm 67.7)$ to $86.4 \pm 89.6(168.6 \pm 101.5) \mu \mathrm{g} \mathrm{m}^{-3}$ during the study period (Table 3). During the study period, the highest daily mean $\mathrm{PM}_{2.5}$ concentration of $511.4 \mu \mathrm{g} \mathrm{m}^{-3}$ which is $\sim 10$ times higher than the national air quality standard level occurred in 2016, while the highest daily-mean $\mathrm{PM}_{10}$ concentration of $833.6 \mu \mathrm{g} \mathrm{m}^{-3}$ ( $\sim 8$ times the national air quality standard level) occurred in 2014. The hourly maximum $\mathrm{PM}_{2.5}$ and $\mathrm{PM}_{10}$ concentrations were recorded as $1413 \mu \mathrm{g} \mathrm{m}^{-3}$ (at Buhiin urguu site at 1 am 16 January 2018) and $2505 \mu \mathrm{g} \mathrm{m}^{-3}$ (at $1-\mathrm{r}$ horoolol site at 3 a.m. 6 February 2018.), respectively. During the 2019-2020 winter, a clear decrease in both $\mathrm{PM}_{2.5}$ and $\mathrm{PM}_{10}$ concentrations was observed. This pattern will be shown in detail in Section Reductions in PM concentrations in Ulaanbaatar during the 2019-2020 winter. The mean temperature ranged from $-17.3 \pm 5.7^{\circ} \mathrm{C}$ to $-13.4 \pm 4.9^{\circ} \mathrm{C}$ for November-February in $2014-2019$ and it was $-14.6 \pm 6.5^{\circ} \mathrm{C}$ in November 2019-February 2020.

Fig. 3 shows the monthly, weekly, and daily variations in the $\mathrm{PM}_{2.5}$ and $\mathrm{PM}_{10}$ concentrations averaged over the air quality monitoring sites during the study period.

Pollutant concentrations have large seasonal variations (Fig. 3(a)). The PM concentrations are found to be higher during winter months, and the concentrations are far above the national standard levels. In Ulaanbaatar, Mongolia, winter season corresponds to the months of December, January, and February (DJF). Both $\mathrm{PM}_{2.5}$ and $\mathrm{PM}_{10}$ concentrations in winter months were much higher than those in other months, with average values in the ranges of $110.6-162.9 \mu^{-3} \mathrm{~m}^{-3}$ for $\mathrm{PM}_{2.5}$ and $169.7-233.0 \mu \mathrm{g} \mathrm{m}^{-3}$ for $\mathrm{PM}_{10}$. The winter values were followed by autumn values $\left(53.1 \mu \mathrm{g} \mathrm{m}^{-3}\right.$ and 119.8 $\mu \mathrm{g} \mathrm{m}^{-3}$ for $\mathrm{PM}_{2.5}$ and $\mathrm{PM}_{10}$, respectively) and spring months (39.1 $\mu \mathrm{g} \mathrm{m}^{-3}$ and $103.5 \mu \mathrm{g} \mathrm{m}^{-3}$ ). The highest concentration occurred in January, followed by December. The mean $\mathrm{PM}_{2.5}$ and $\mathrm{PM}_{10}$ concentrations in summer were 6.7 and 2.7 times, respectively, lower than in winter months. The lowest concentrations occurred in July-August $\mathrm{PM}_{2.5}$ and for JuneJuly for $\mathrm{PM}_{10}$.

The monthly-mean $\mathrm{PM}_{2.5} / \mathrm{PM}_{10}$ ratio was 0.44 , which was in agreement with investigations in other cities in Asia, with $\mathrm{PM}_{2.5} / \mathrm{PM}_{10}$ ratio values of less than 0.5 indicating higher than coarse particle masses (Hopke et al., 2008). The ratio was large (small) in winter and small (low) in summer months. These ratios are consistent with previous findings by Allen et al. (2013) in Ulaanbaatar. In April and May, the $\mathrm{PM}_{10}$ concentrations were still high, which can be explained by the predominance of large particles, indicating crustal dust storm events that frequently occur in spring in the relatively dry and windy seasons (Davy et al., 2011).

The daily mean $\mathrm{PM}_{2.5}$ and $\mathrm{PM}_{10}$ concentrations during the study period significantly exceeded the national air quality standard levels. The daily mean concentrations were slightly higher on workdays than on weekends (Fig. 3(b)). The lowest concentrations were recorded during the weekend- 60.7 $\mu \mathrm{g} \mathrm{m}^{-3}$ for $\mathrm{PM}_{2.5}$ and $117.9 \mu \mathrm{g} \mathrm{m}^{-3}$ for $\mathrm{PM}_{10}$. The variations in day by day peaks of $\mathrm{PM}_{2.5}$ and $\mathrm{PM}_{10}$ concentrations were different - the largest $\mathrm{PM}_{2.5}$ concentrations occurred on Thursday and Friday $\left(67.9 \mu \mathrm{g} \mathrm{m}^{-3}\right.$ and $67.7 \mu \mathrm{g} \mathrm{m}^{-3}$, respectively), while the highest daily mean $\mathrm{PM}_{10}$ concentrations occurred on Tuesday and Friday $\left(130.0 \mu \mathrm{g} \mathrm{m}^{-3}\right.$ and 131.0 $\mu \mathrm{g} \mathrm{m}^{-3}$, respectively). This finding with higher concentrations on workdays than weekends has also been observed in other 
cities of the world (Adame et al., 2014; Lim et al., 2018). This is mainly caused by workday activities but the concentrations behavior at each site is different, a detailed investigation will be done in the future.
Daily variations in $\mathrm{PM}_{2.5}$ and $\mathrm{PM}_{10}$ concentrations showed strong variations due to anthropogenic activities and planetary boundary layer evolution inclusive the day and night wind field system, which is still under investigation

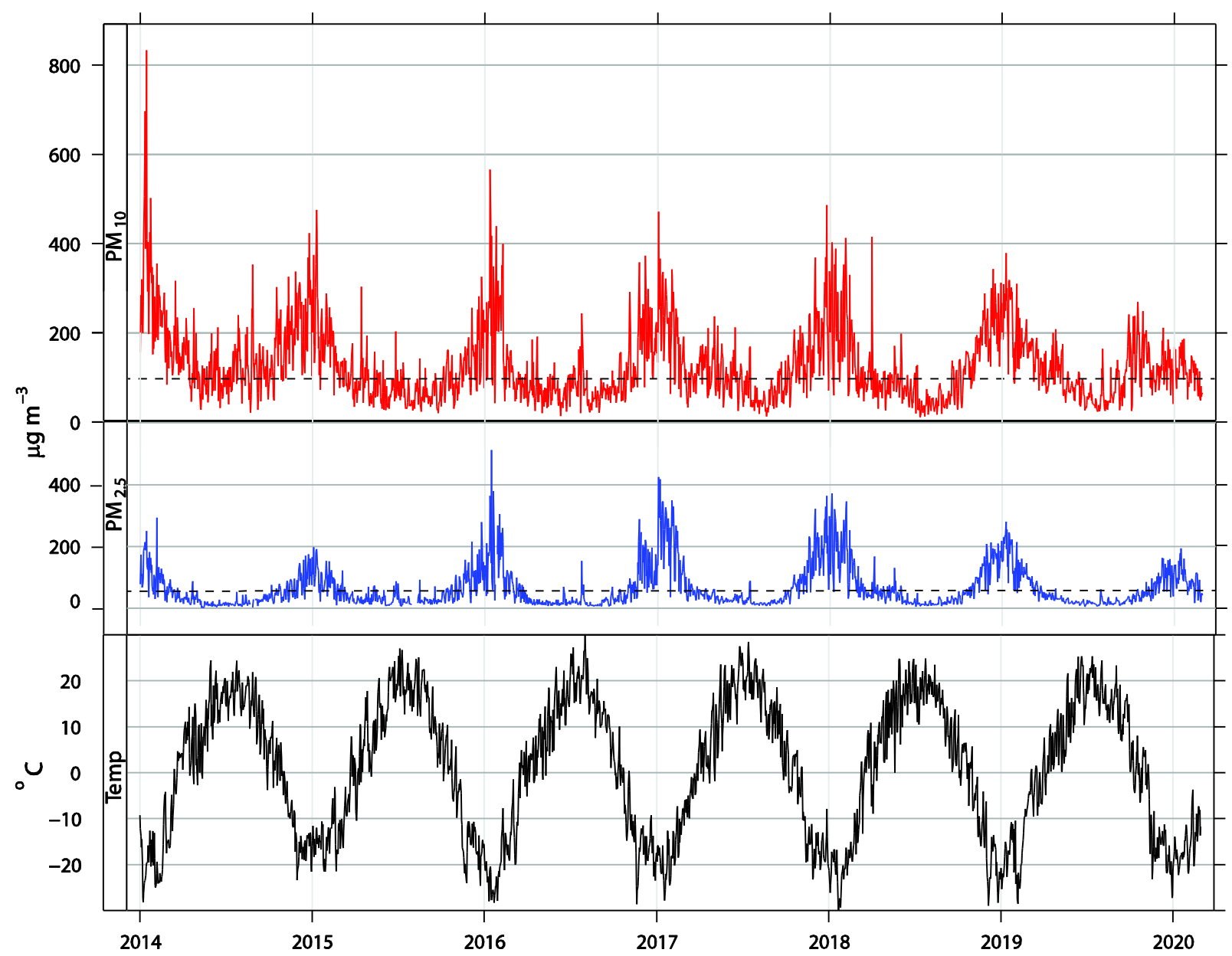

Fig. 2. Time series of daily mean $\mathrm{PM}_{2.5}$ (blue), $\mathrm{PM}_{10}$ (red) concentrations and temperature at Ulaanbaatar (44292) station (black) for the period January 2014-February 2020. The concentrations are averaged over the air quality monitoring sites. Horizontal dashed lines indicate the 24-h average standard air pollution levels of $\mathrm{PM}_{2.5}$ and $\mathrm{PM}_{10}\left(50 \mu \mathrm{g} \mathrm{m}^{-3}\right.$ and $100 \mu \mathrm{g} \mathrm{m}{ }^{-3}$, respectively).

Table 3. Mean and maximum $\mathrm{PM}_{2.5}$ and $\mathrm{PM}_{10}$ concentrations.

\begin{tabular}{|c|c|c|c|c|c|c|}
\hline Pollutant & 2014 & 2015 & 2016 & 2017 & 2018 & 2019 \\
\hline \multicolumn{7}{|c|}{ Yearly mean } \\
\hline $\mathrm{PM}_{2.5}$ & 50.0 & 52.5 & 59.8 & 86.4 & 74.9 & 57.9 \\
\hline $\mathrm{PM}_{10}$ & 168.6 & 106.3 & 114.5 & 127.1 & 120.3 & 120.3 \\
\hline \multicolumn{7}{|c|}{ Yearly maximum } \\
\hline $\mathrm{PM}_{2.5}$ & 293.0 & 278.5 & 511.4 & 424.2 & 371.9 & 279.8 \\
\hline \multirow[t]{2}{*}{$\mathrm{PM}_{10}$} & 833.6 & 475.6 & 566.1 & 486.0 & 415.5 & 379.0 \\
\hline & $\begin{array}{l}\text { Nov 2014-Feb } \\
2015\end{array}$ & $\begin{array}{l}\text { Nov 2015-Feb } \\
2016\end{array}$ & $\begin{array}{l}\text { Nov 2016-Feb } \\
2017\end{array}$ & $\begin{array}{l}\text { Nov 2017-Feb } \\
2018\end{array}$ & $\begin{array}{l}\text { Nov } 2018-F e b \\
2019\end{array}$ & $\begin{array}{l}\text { Nov 2019-Feb } \\
2020\end{array}$ \\
\hline \multicolumn{7}{|c|}{ Daily mean } \\
\hline $\mathrm{PM}_{2.5}$ & 86.4 & 120.3 & 163.9 & 170.7 & 138.4 & 87.6 \\
\hline $\mathrm{PM}_{10}$ & 207.1 & 172.3 & 194.0 & 196.2 & 205.4 & 117.0 \\
\hline \multicolumn{7}{|c|}{ Daily maximum } \\
\hline $\mathrm{PM}_{2.5}$ & 197.9 & 511.4 & 424.3 & 371.9 & 279.8 & 194.1 \\
\hline $\mathrm{PM}_{10}$ & 475.6 & 566.1 & 471.7 & 486.0 & 379.0 & 211.3 \\
\hline
\end{tabular}


(a)

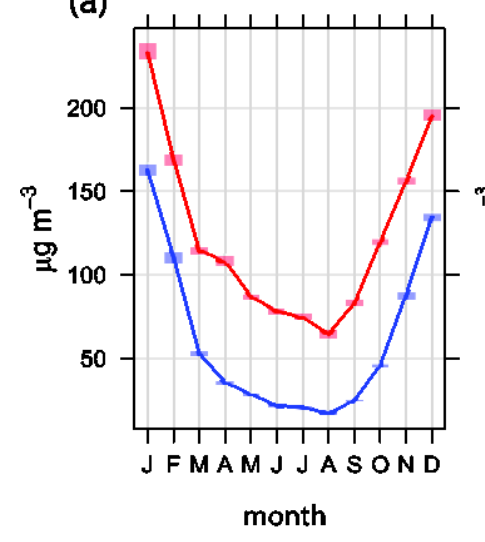

(b)

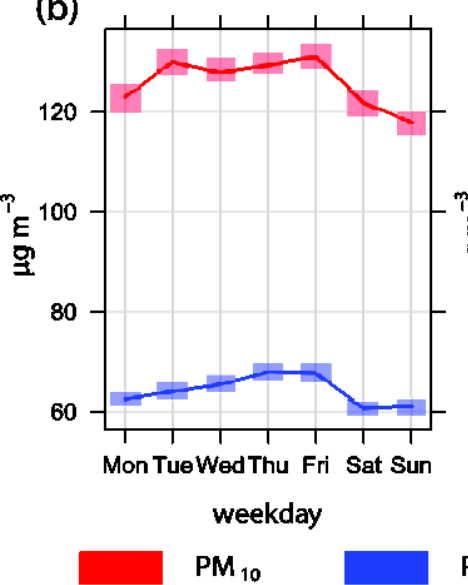

(c)

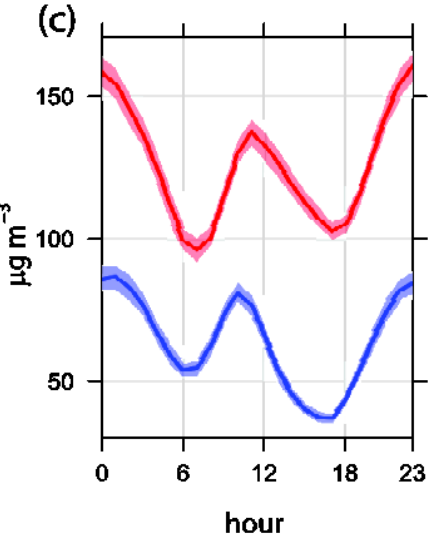

Fig. 3. (a) Monthly, (b) weekly, and (c) daily variations in $\mathrm{PM}_{2.5}$ (blue) and $\mathrm{PM}_{10}$ (red) concentrations for the study period averaged over the air quality monitoring sites. Color shadings indicate standard deviations $(\sigma)$.

and not part of this short paper. The daily variation showed a "W"-like shape, with the lowest concentration appearing at approximately 7 a.m. and 4-5 p.m. for $\mathrm{PM}_{2.5}$ and $\mathrm{PM}_{10}$, respectively. Two peaks of $\mathrm{PM}_{2.5}$ and $\mathrm{PM}_{10}$ concentrations appeared between 10 a.m. and 11 a.m., respectively, as well as around midnight. The increase in the morning could be explained by a "rush hour" due to cooking and space heating and traffic resuspension and particle emissions, while the primary emissions made an important contribution at night. This concentration pattern is in agreement with previously identified daily variations in $\mathrm{PM}_{2.5}$ in Ulaanbaatar (Allen et al., 2013). However, the seasonal pattern can be different depending on the coal combustion activities for cooking and heating purposes. For example, coal consumption in the morning in winter and autumn likely results in the first peak of the diurnal course in $\mathrm{PM}_{2.5}$ and $\mathrm{PM}_{10}$ concentrations (not shown).

The daily patterns with bimodal peaks of PM concentrations in Ulaanbaatar were very similar to those in other cities, e.g., Seoul, South Korea (Kim et al., 2020), Beijing, China (Liu et al., 2014) and at the urban background and urban traffic sites in Andalusia, Spain (Adame et al., 2014). Decreases and increases in hourly mean $\mathrm{PM}_{2.5}$ and $\mathrm{PM}_{10}$ concentrations throughout the day could also be explained by changes in the boundary layer height and temperature inversion layer. A increased boundary layer height and a resolving temperature inversion with weakened strength and thickness in the daytime (Ganbat and Baik, 2016) are beneficial to the vertical distribution/exchange/mixture of pollutants, which results in a reduction of mean pollutant concentrations at ground level in the afternoon.

\section{REDUCTIONS IN PM CONCENTRATIONS IN ULAANBAATAR DURING THE 2019-2020 WINTER}

Since the replacement program of the consumption of raw coal with briquette fuel became active, marked improvement in air quality has been recorded in Ulaanbaatar, and the public witnessed better air quality during the 2019-2020 winter.

Fig. 4 shows the daily mean $\mathrm{PM}_{10}$ concentrations for the cold months (November-February) for the whole study period (2014-2020) using a color graduation corresponding levels of between zero (light yellow) to $400 \mu \mathrm{g} \mathrm{m}^{-3}$ (dark red-brown). The mean $\mathrm{PM}_{2.5}$ concentrations for NovemberFebruary were $86.4 \pm 41.8,120.3 \pm 78.9,163.9 \pm 94.1,170.7$ $\pm 79.7,138.4 \pm 53.2$, and $87.6 \pm 37.6 \mu \mathrm{g} \mathrm{m}^{-3}$ in 2014-2015 2015-2016, 2016-2017, 2017-2018, 2018-2019, and 20192020, respectively. The mean $\mathrm{PM}_{10}$ concentrations for November-February are 207.1 $\pm 78.7,172.3 \pm 95.9,194.0 \pm$ $79.6,196.2 \pm 92.3,205.4 \pm 60.9$, and $117.0 \pm 36.5 \mu \mathrm{g} \mathrm{m}^{-3}$ in 2014-2015, 2015-2016, 2016-2017, 2017-2018, 20182019, and 2019-2020, respectively. The mean NovemberFebruary $\mathrm{PM}_{2.5}$ and $\mathrm{PM}_{10}$ concentrations were reduced by $37 \%$ and $40 \%$ compared to the mean November-February concentrations of the previous 5 years, respectively.

The daily mean PM concentrations clearly exhibit a decreasing trend in November 2019-February 2020 (Fig. 4). In the previous five years, in the most polluted month, January, the number of days with $\mathrm{PM}_{10}$ concentrations above $250 \mu \mathrm{g} \mathrm{m}^{-3}$ is $25-35$ and extremely highly polluted days with daily mean $\mathrm{PM}_{10}$ concentrations above $350 \mu \mathrm{g} \mathrm{m}^{-3}$ occurred 1-7 times. The maximum $\mathrm{PM}_{2.5}\left(\mathrm{PM}_{10}\right)$ concentrations

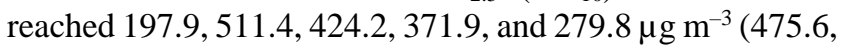
566.1, 471.7, 486.0, and $379.0 \mu \mathrm{g} \mathrm{m}^{-3}$ ) for NovemberFebruary in 2014-2015, 2015-2016, 2016-2017, 20172018, and 2018-2019, respectively. In contrast, during January 2020 , there was no day with a $\mathrm{PM}_{10}$ concentration exceeding $250 \mu \mathrm{g} \mathrm{m}^{-3}$. The maximum daily mean $\mathrm{PM}_{2.5}$ and $\mathrm{PM}_{10}$ concentrations were recorded as $194.1 \mathrm{\mu g} \mathrm{m}^{-3}$ and $211.3 \mu \mathrm{g} \mathrm{m}^{-3}$ during the 2019-2020 winter, respectively, which indicate $46 \%$ and $55 \%$ reductions of PM concentrations in the previous five years (2014-2019).

For winters before 2019, the days exceeding the $\mathrm{PM}_{10}$ standard level constituted 78-98\% of all days, but it decreased to $\sim 67 \%$ for the $2019-2020$ winter. Table 4 supplements Fig. 4 and provides the number of polluted days with average PM concentrations during November-February exceeding 1,2, and 3 times the national air quality standard levels of $50 \mu \mathrm{g} \mathrm{m}^{-3}$ (for $\mathrm{PM}_{2.5}$ ) and $100 \mu \mathrm{g} \mathrm{m}^{-3}$ (for $\mathrm{PM}_{10}$ ). Notably, days with an average PM concentration exceeding 


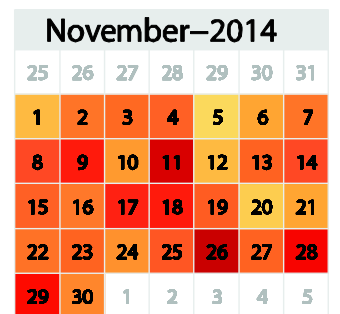

S S M T W T

November-2015

$\begin{array}{lllllll}31 & 1 & 2 & 3 & 4 & 5 & 6\end{array}$

\begin{tabular}{|l|l|l|l|l|l|l|}
7 & 8 & 9 & 10 & 11 & 12 & 13 \\
\hline
\end{tabular}

\begin{tabular}{lllll|l|l|l|}
14 & 15 & 16 & 17 & 18 & 19 & 20
\end{tabular}

\begin{tabular}{llll|l|l|l|}
21 & 22 & 23 & 24 & 25 & 26 & 27
\end{tabular}

$\begin{array}{llll}28 & 29 & 30\end{array}$

$\begin{array}{lllllllll}5 & 6 & 7 & 8 & 9 & 10 & 11\end{array}$

$S \quad S \quad M \quad T \quad W \quad T \quad F$

November-2016

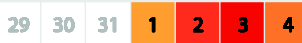

\begin{tabular}{ll|l|l|l|l|l}
5 & 6 & 7 & 8 & 9 & 10 & 11
\end{tabular}

$\begin{array}{lllllllll}12 & 13 & 14 & 15 & 16 & 17 & 18\end{array}$

\begin{tabular}{l|l|l|l|l|l|l|}
19 & 20 & 21 & 22 & 23 & 24 & 25
\end{tabular}

\begin{tabular}{|l|l|l|l|l|}
26 & 27 & 28 & 29 & 30
\end{tabular}

S S M T W T F

November-2017

\begin{tabular}{llllll|l|l|}
28 & 29 & 30 & 31 & $\mathbf{1}$ & $\mathbf{2}$ & $\mathbf{3}$
\end{tabular}

\begin{tabular}{|c|c|c|c|c|c|c|}
\hline 4 & 5 & 6 & 7 & 8 & 9 & 10 \\
\hline 11 & 12 & 13 & 14 & 15 & 16 & 17 \\
\hline
\end{tabular}

\begin{tabular}{lllll|l|l|l|}
11 & 12 & 13 & 14 & 15 & 16 & 17
\end{tabular}

\begin{tabular}{|l|l|l|l|l|l|l|}
18 & 19 & 20 & 21 & 22 & 23 & 24 \\
\hline
\end{tabular}

\begin{tabular}{l|l|l|l|l|l|}
25 & 26 & 27 & 28 & 29 & 30
\end{tabular}

\section{S S M T W T F}

November-2018

\begin{tabular}{|l|l|l|l|l|l|l|}
27 & 28 & 29 & 30 & 31 & $\mathbf{1}$ & $\mathbf{2}$ \\
\hline $\mathbf{3}$ & $\mathbf{4}$ & $\mathbf{5}$ & $\mathbf{6}$ & $\mathbf{7}$ & $\mathbf{8}$ & $\mathbf{9}$ \\
\hline
\end{tabular}

\begin{tabular}{|c|c|c|c|c|c|c|}
\hline 3 & 4 & 5 & 6 & 7 & 8 & 9 \\
\hline 10 & 11 & 12 & 13 & 14 & 15 & 16 \\
\hline
\end{tabular}

\begin{tabular}{|l|l|l|l|l|l|l|}
17 & 18 & 19 & 20 & 21 & 22 & 23 \\
\hline
\end{tabular}

\begin{tabular}{|l|l|l|l|l|l|l|}
24 & 25 & 26 & 27 & 28 & 29 & 30
\end{tabular}

S S M T W T

November-2019

\begin{tabular}{|l|l|l|l|l|l|l|}
\hline 26 & 27 & 28 & 29 & 30 & 31 & $\mathbf{1}$ \\
\hline $\mathbf{2}$ & $\mathbf{3}$ & $\mathbf{4}$ & $\mathbf{5}$ & $\mathbf{6}$ & $\mathbf{7}$ & $\mathbf{8}$ \\
\hline
\end{tabular}

\begin{tabular}{|l|l|l|l|l|l|l|}
9 & 10 & 11 & 12 & 13 & 14 & 15 \\
\hline
\end{tabular}

\begin{tabular}{l|l|l|l|l|l|l|}
16 & 17 & 18 & 19 & 20 & 21 & 22
\end{tabular}

\begin{tabular}{l|l|l|l|l|l|l|}
23 & 24 & 25 & 26 & 27 & 28 & 29
\end{tabular}

\begin{tabular}{|l|l|l|l|l|l|l|}
30 & 1 & 2 & 3 & 4 & 5 & 6
\end{tabular}

$\begin{array}{lllllll}S & S & M & T & W & T & F\end{array}$
December-2014

\begin{tabular}{|c|c|c|c|c|c|c|}
29 & 30 & $\mathbf{1}$ & $\mathbf{2}$ & $\mathbf{3}$ & 4 & $\mathbf{5}$ \\
\hline 6 & 7 & 8 & 9 & 10 & 11 & 12
\end{tabular}

\begin{tabular}{|l|l|l|l|l|l|l|}
13 & 14 & 15 & 16 & 17 & 18 & 19
\end{tabular}

\begin{tabular}{|l|l|l|l|l|l|l|}
20 & 21 & 22 & 23 & 24 & 25 & 26
\end{tabular}

\begin{tabular}{l|l|l|l|l|l|l|}
27 & 28 & 29 & 30 & 31 & 1 & 2
\end{tabular}

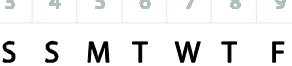

December-2015

$\begin{array}{lllllll}28 & 29 & 30 & 1 & \mathbf{2} & \mathbf{3}\end{array}$

\begin{tabular}{|l|l|l|l|l|l|l|}
5 & 6 & 7 & 8 & 9 & 10 & 11
\end{tabular}

\begin{tabular}{|l|l|l|l|l|l|l|}
12 & 13 & 14 & 15 & 16 & 17 & 18 \\
\hline
\end{tabular}

\begin{tabular}{l|l|l|l|l|l|l|}
19 & 20 & 21 & 22 & 23 & 24 & 25
\end{tabular}

\begin{tabular}{l|l|l|l|l|l|l|}
26 & 27 & 28 & 29 & 30 & 31 \\
\hline
\end{tabular}

$\begin{array}{lllllll}S & S & M & T & W & T & F\end{array}$

December-2016

\begin{tabular}{|l|l|l|l|l|l|l|}
26 & 27 & 28 & 29 & 30 & 1 & 2
\end{tabular}

\begin{tabular}{|l|l|l|l|l|l|l|}
\hline 3 & 4 & 5 & 6 & 7 & 8 & 9 \\
\hline
\end{tabular}

\begin{tabular}{|l|l|l|l|l|l|l|}
10 & 11 & 12 & 13 & 14 & 15 & 16 \\
\hline
\end{tabular}

$\begin{array}{lllllllll}17 & 18 & 19 & 20 & 21 & 22 & 23\end{array}$

\begin{tabular}{|l|l|l|l|l|l|l|}
24 & 25 & 26 & 27 & 28 & 29 & 30 \\
\hline
\end{tabular}

\begin{tabular}{l|l|l|l|l|l|l}
31 & 1 & 2 & 3 & 4 & 5 & 6
\end{tabular}

$\begin{array}{lllllll}S & S & M & T & W & T & F\end{array}$

December-2017

$\begin{array}{llllll}25 & 26 & 27 & 28 & 29 & 30\end{array}$

\begin{tabular}{l|l|l|l|l|l|l|}
2 & 3 & 4 & 5 & 6 & 7 & 8 \\
\hline
\end{tabular}

\begin{tabular}{|l|l|l|l|l|l|l|}
\hline 9 & 10 & 11 & 12 & 13 & 14 & 15 \\
\hline
\end{tabular}

\begin{tabular}{|l|l|l|l|l|l|l|}
\hline 16 & 17 & 18 & 19 & 20 & 21 & 22 \\
\hline
\end{tabular}

\begin{tabular}{l|l|l|l|l|l|l|}
23 & 24 & 25 & 26 & 27 & 28 & 29
\end{tabular} \begin{tabular}{l|l|l|l|l|l|l|}
\hline 30 & 31 & 1 & 2 & 3 & 4 & 5
\end{tabular}

$\begin{array}{lllllll}\text { S } & S & \text { M } & \text { T } & \text { W } & \text { T } & \text { F }\end{array}$

December-2018

$\begin{array}{llllllll}24 & 25 & 26 & 27 & 28 & 29 & 30\end{array}$

\begin{tabular}{|l|l|l|l|l|l|l|}
1 & 2 & 3 & 4 & 5 & 6 & 7
\end{tabular}

\begin{tabular}{|l|l|l|l|l|l|l|}
\hline 8 & 9 & 10 & 11 & 12 & 13 & 14 \\
\hline
\end{tabular}

\begin{tabular}{|l|l|l|l|l|l|l|}
15 & 16 & 17 & 18 & 19 & 20 & 21 \\
\hline
\end{tabular}

\begin{tabular}{l|l|l|l|l|l|l|}
22 & 23 & 24 & 25 & 26 & 27 & 28
\end{tabular}

\begin{tabular}{|l|l|l|l|l|l|l|}
\hline 29 & 30 & 31 & 1 & 2 & 3 & 4
\end{tabular}

S S M T W T F

December-2019

\begin{tabular}{|l|l|l|l|l|l|l|}
30 & 1 & 2 & 3 & 4 & 5 & 6
\end{tabular}

\begin{tabular}{|l|l|l|l|l|l|l|}
7 & 8 & 9 & 10 & 11 & 12 & 13 \\
\hline
\end{tabular}

\begin{tabular}{|l|l|l|l|l|l|l|}
14 & 15 & 16 & 17 & 18 & 19 & 20 \\
\hline
\end{tabular}

\begin{tabular}{l|l|l|l|l|l|l|}
21 & 22 & 23 & 24 & 25 & 26 & 27
\end{tabular}

\begin{tabular}{|l|l|l|l|l|l|l|}
28 & 29 & 30 & 31 & 1 & 2 & 3
\end{tabular}

$S \quad S \quad M \quad T \quad W \quad F$
January-2015

\begin{tabular}{ll|lllll|l}
27 & 28 & 29 & 30 & 31 & $\mathbf{1}$ & $\mathbf{2}$
\end{tabular}

\begin{tabular}{|l|l|l|l|l|l|l|}
3 & 4 & 5 & 6 & 7 & 8 & 9 \\
\hline
\end{tabular}

\begin{tabular}{l|l|l|l|l|l|l|}
10 & 11 & 12 & 13 & 14 & 15 & 16 \\
\hline
\end{tabular}

\begin{tabular}{llll|l|l|l|l|}
17 & 18 & 19 & 20 & 21 & 22 & 23
\end{tabular}

\begin{tabular}{l|l|l|l|l|l|l|}
24 & 25 & 26 & 27 & 28 & 29 & 30
\end{tabular}

\begin{tabular}{|l|l|l|l|l|l|l|}
\hline 31 & 1 & 2 & 3 & 4 & 5 & 6
\end{tabular}

$\begin{array}{lllllll}S & S & M & T & W & T & F\end{array}$

Januany-2016

\begin{tabular}{|c|c|c|c|c|c|c|}
\hline 26 & 27 & 28 & 29 & 30 & 31 & 1 \\
\hline $\mathbf{2}$ & $\mathbf{3}$ & $\mathbf{4}$ & $\mathbf{5}$ & $\mathbf{6}$ & $\mathbf{7}$ & $\mathbf{8}$ \\
\hline
\end{tabular}

\begin{tabular}{|l|l|l|l|l|l|l|}
\hline 9 & 10 & 11 & 12 & 13 & 14 & 15 \\
\hline
\end{tabular}

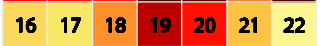

\begin{tabular}{|l|l|l|l|l|l|l|}
23 & 24 & 25 & 26 & 27 & 28 & 29 \\
\hline
\end{tabular}

\begin{tabular}{l|lllllll}
$\mathbf{3 0}$ & 31 & 1 & 2 & 3 & 4 & 5
\end{tabular}

S S $\quad$ M T $\quad$ W $\quad$ T $\quad F$

January-2017

\begin{tabular}{|l|l|l|l|l|l|l|}
31 & 1 & 2 & 3 & 4 & 5 & 6
\end{tabular}

\begin{tabular}{|l|l|l|l|l|l|l|}
7 & 8 & 9 & 10 & 11 & 12 & 13 \\
\hline
\end{tabular}

\begin{tabular}{l|l|l|l|l|l|l|}
14 & 15 & 16 & 17 & 18 & 19 & 20 \\
\hline
\end{tabular}

\begin{tabular}{l|l|l|l|l|l|l|}
21 & 22 & 23 & 24 & 25 & 26 & 27
\end{tabular}

\begin{tabular}{|l|l|l|l|l|l|l|}
28 & 29 & 30 & 31 & 1 & 2 & 3
\end{tabular}

\begin{tabular}{lll|l|l|l|l}
4 & 5 & 6 & 7 & 8 & 9 & 10
\end{tabular}

$\begin{array}{lllllll}S & S & M & T & W & T & F\end{array}$ January-2018

\begin{tabular}{|l|l|l|l|l|l|l|}
30 & 31 & $\mathbf{1}$ & $\mathbf{2}$ & $\mathbf{3}$ & $\mathbf{4}$ & 5 \\
\hline
\end{tabular}

$\begin{array}{lllllll}7 & 8 & 9 & 10 & 11 & 12\end{array}$ \begin{tabular}{|l|l|l|l|l|l|}
14 & 15 & 16 & 17 & 18 & 19 \\
\hline
\end{tabular} \begin{tabular}{llll|l|l|l|}
20 & 21 & 22 & 23 & 24 & 25 & 26
\end{tabular}

\begin{tabular}{|l|l|l|l|l|l|}
\hline 27 & 28 & 29 & 30 & 31
\end{tabular}

S S M T W T F

January-2019

\begin{tabular}{|l|l|l|l|l|l|l|}
29 & 30 & 31 & 1 & 2 & 3 & 4
\end{tabular}

\begin{tabular}{|l|l|l|l|l|l|l|}
\hline 5 & 6 & 7 & 8 & 9 & 10 & 11 \\
\hline
\end{tabular}

\begin{tabular}{|l|l|l|l|l|l|l|}
12 & 13 & 14 & 15 & 16 & 17 & 18 \\
\hline
\end{tabular}

\begin{tabular}{|l|l|l|l|l|l|l|}
19 & 20 & 21 & 22 & 23 & 24 & 25
\end{tabular}

\begin{tabular}{llllll|l|l}
26 & 27 & 28 & 29 & 30 & 31 & 1
\end{tabular}

\begin{tabular}{l|l|l|l|l|l|l}
\hline 2 & 3 & 4 & 5 & 6 & 7 & 8
\end{tabular}

$\begin{array}{lllllll}S & S & M & T & \text { W } & T & F\end{array}$ January-2020

\begin{tabular}{lllll|l|l|}
28 & 29 & 30 & 31 & 1 & $\mathbf{2}$ & $\mathbf{3}$
\end{tabular}

\begin{tabular}{|c|c|c|c|c|c|c|}
\hline 4 & 5 & 6 & 7 & 8 & 9 & 10 \\
\hline 11 & 12 & 13 & 14 & 15 & 16 & 17 \\
\hline
\end{tabular}

\begin{tabular}{|l|l|l|l|l|l|l|}
11 & 12 & 13 & 14 & 15 & 16 & 17 \\
\hline
\end{tabular}

\begin{tabular}{|l|l|l|l|l|l|l|}
18 & 19 & 20 & 21 & 22 & 23 & 24 \\
\hline
\end{tabular}

\begin{tabular}{ll|l|l|l|l|l}
25 & 26 & 27 & 28 & 29 & 30 & 31
\end{tabular}

$\begin{array}{lllllll}S & S & M & T & W & T & F\end{array}$
February-2015

\begin{tabular}{|l|l|l|l|l|l|l|}
31 & 1 & 2 & 3 & 4 & 5 & 6 \\
\hline & 8 & 9 & 10 & 11 & 12 & 13 \\
\hline
\end{tabular}

\begin{tabular}{|l|l|l|l|l|l|l|}
7 & 8 & 9 & 10 & 11 & 12 & 13 \\
\hline
\end{tabular}

\begin{tabular}{|l|l|l|l|l|l|l|}
14 & 15 & 16 & 17 & 18 & 19 & 20 \\
\hline
\end{tabular}

\begin{tabular}{|l|l|l|l|l|l|l|}
\hline 21 & 22 & 23 & 24 & 25 & 26 & 27
\end{tabular}

\begin{tabular}{|l|l|l|l|l|l|l|}
\hline 28 & 1 & 2 & 3 & 4 & 5 & 6
\end{tabular}

\begin{tabular}{ll|l|l|l|l|l|}
7 & 8 & 9 & 10 & 11 & 12 & 13
\end{tabular}

S S M T W T F

February-2016

\begin{tabular}{|l|l|l|l|l|l|l|}
30 & 31 & 1 & 2 & 3 & 4 & 5 \\
\hline
\end{tabular}

\begin{tabular}{|l|l|l|l|l|l|l|}
\hline 6 & 7 & 8 & 9 & 10 & 11 & 12 \\
\hline 13 & 14 & 15 & 16 & 17 & 18 & 19 \\
\hline
\end{tabular}

\begin{tabular}{|l|l|l|l|l|l|l|}
13 & 14 & 15 & 16 & 17 & 18 & 19 \\
\hline
\end{tabular}

\begin{tabular}{llll|l|l|l|}
20 & 21 & 22 & 23 & 24 & 25 & 26
\end{tabular}

\begin{tabular}{l|l|l|l|l|l|l|}
27 & 28 & 29 & 1 & 2 & 3 & 4
\end{tabular}

\begin{tabular}{|l|l|l|l|l|l|l|}
5 & 6 & 7 & 8 & 9 & 10 & 11
\end{tabular}

S S M T W T $\quad F$

February-2017

\begin{tabular}{l|l|l|l|l|l|l|}
28 & 29 & 30 & 31 & $\mathbf{1}$ & $\mathbf{2}$ & $\mathbf{3}$ \\
\hline
\end{tabular}

\begin{tabular}{|c|c|c|c|c|c|c|}
\hline 4 & 5 & 6 & 7 & 8 & 9 & 10 \\
\hline 11 & 12 & 13 & 14 & 15 & 16 & 17
\end{tabular}

\begin{tabular}{l|l|l|l|l|l|l|}
11 & 12 & 13 & 14 & 15 & 16 & 17
\end{tabular}

\begin{tabular}{|l|l|l|l|l|l|l|}
18 & 19 & 20 & 21 & 22 & 23 & 24 \\
\hline
\end{tabular}

\begin{tabular}{|l|l|l|l|l|l|l|}
25 & 26 & 27 & 28 & 1 & 2 & 3
\end{tabular}

S S M T W T F

February-2018

\begin{tabular}{l|l|lll|l|l|}
27 & 28 & 29 & 30 & 31 & 1 & 2
\end{tabular}

\begin{tabular}{l|l|l|l|l|l|l|}
3 & 4 & 5 & 6 & 7 & 8 & 9
\end{tabular}

\begin{tabular}{|l|l|l|l|l|l|l|}
10 & 11 & 12 & 13 & 14 & 15 & 16 \\
\hline 17 & 18 & 19 & 20 & 21 & 22 & 23 \\
\hline
\end{tabular}

\begin{tabular}{l|l|l|l|l|l|l|}
17 & 18 & 19 & 20 & 21 & 22 & 23
\end{tabular}

\begin{tabular}{|l|l|l|l|l|l|l|}
24 & 25 & 26 & 27 & 28 & 1 & 2
\end{tabular}

S S M T W T F

February-2019

\begin{tabular}{|c|c|c|c|c|c|c|}
\hline 26 & 27 & 28 & 29 & 30 & 31 & $\mathbf{1}$ \\
$\mathbf{2}$ & $\mathbf{3}$ & $\mathbf{4}$ & $\mathbf{5}$ & $\mathbf{6}$ & $\mathbf{7}$ & $\mathbf{8}$ \\
\hline
\end{tabular}

\begin{tabular}{|l|l|l|l|l|l|l|}
9 & 10 & 11 & 12 & 13 & 14 & 15 \\
\hline
\end{tabular}

\begin{tabular}{|l|l|l|l|l|l|l|}
16 & 17 & 18 & 19 & 20 & 21 & 22 \\
\hline
\end{tabular}

\begin{tabular}{l|l|l|l|l|l|l|}
23 & 24 & 25 & 26 & 27 & 28 & 1
\end{tabular}

$\begin{array}{llllllll}2 & 3 & 4 & 5 & 6 & 7 & 8\end{array}$

$\begin{array}{lllllll}S & S & M & T & W & T & F\end{array}$

February-2020

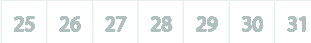

\begin{tabular}{|l|l|l|l|l|l|l|}
\hline 1 & 2 & 3 & 4 & 5 & 6 & 7 \\
\hline
\end{tabular}

\begin{tabular}{|l|l|l|l|l|l|l|}
8 & 9 & 10 & 11 & 12 & 13 & 14 \\
\hline
\end{tabular}

\begin{tabular}{|l|l|l|l|l|l|l|}
15 & 16 & 17 & 18 & 19 & 20 & 21
\end{tabular}

$\begin{array}{llllllll}22 & 23 & 24 & 25 & 26 & 27 & 28\end{array}$

\begin{tabular}{l|l|l|l|l|l|l|}
29 & 1 & 2 & 3 & 4 & 5 & 6
\end{tabular}

S S M T W T

$\mu \mathrm{g} \mathrm{m}^{-3}$

$$
50
$$

100

150

200

300

$350>400$

Fig. 4. Daily mean concentrations of $\mathrm{PM}_{10}$ for November-February during the study period. 
Table 4. Days with average concentrations exceeding the national air quality standard levels of $\mathrm{PM}_{10}$ and $\mathrm{PM}_{2.5}$.

\begin{tabular}{lllllllll}
\hline & $\begin{array}{l}\text { Exceedance } \\
\text { factor }\end{array}$ & $\begin{array}{l}\text { Concentration, } \\
\mu \mathrm{g} \mathrm{m}{ }^{-3}\end{array}$ & $\begin{array}{l}\text { Nov 2014- } \\
\text { Feb 2015 }\end{array}$ & $\begin{array}{l}\text { Nov 2015- } \\
\text { Feb 2016 }\end{array}$ & $\begin{array}{l}\text { Nov 2016- } \\
\text { Feb 2017 }\end{array}$ & $\begin{array}{l}\text { Nov 2017- } \\
\text { Feb 2018 }\end{array}$ & $\begin{array}{l}\text { Nov 2018- } \\
\text { Feb 2019 }\end{array}$ & $\begin{array}{l}\text { Nov 2019- } \\
\text { Feb 2020 }\end{array}$ \\
\hline $\mathrm{PM}_{2.5}$ & 1 & $\geq 50$ & 95 & 103 & 110 & 116 & 116 & 98 \\
& 2 & $\geq 100$ & 42 & 65 & 84 & 94 & 91 & 42 \\
$\mathrm{PM}_{10}$ & 3 & $\geq 150$ & 13 & 32 & 59 & 65 & 46 & 8 \\
& 1 & $\geq 100$ & 115 & 93 & 103 & 103 & 117 & 81 \\
& 2 & $\geq 200$ & 56 & 35 & 56 & 51 & 52 & 3 \\
\\
3
\end{tabular}

1 time indicate the days with an average PM concentration above the national air quality standard levels. For winters before 2019, but 2019-2020 winter, the average number of days exceeding the $\mathrm{PM}_{2.5}$ concentration was 106.2, and reduced to 81 . For winters before 2019, but 2019-2020 winter, the average number of days exceeding the $\mathrm{PM}_{10}$ concentration was 108 , and reduced to 98 . It became evident that the number of days with an average $\mathrm{PM}_{2.5}$ concentration exceeding 2 times the national air quality standard level increased dramatically each year during the period of 20142019. The number of days exceeding 2 (3) times the $\mathrm{PM}_{2.5}$ standard level also rose nearly 2 (3) times from 2014 to 2018. For winters before 2019, the number of days with average $\mathrm{PM}_{2.5}$ concentrations exceeding 3 times the national air quality standard level ranged from 13-46, but for 20192020 winter, it was reduced to 8. For the 2019-2020 winter, there were no days ( 3 days) with average $\mathrm{PM}_{10}$ concentrations exceeding 3 (2) times the national air quality standard level.

Fig. 5 shows the histograms of the frequency or count distribution of $\mathrm{PM}_{2.5}$ and $\mathrm{PM}_{10}$ concentrations for NovemberFebruary for the study period. In general, before 2019, the distributions of frequency occurrence appeared in a wider range when compared to the 2019-2020 winter. For $\mathrm{PM}_{2.5}$, the percentage exceeding the national standard level constituted 79.2-96.7\% for November-February 20142019 and it was changed to $80.9 \%$ for November-February 2019-2020. For $\mathrm{PM}_{10}$, the percentage exceeding the national standard level constituted $77.5-97.5 \%$ for NovemberFebruary 2014-2019 and it was reduced to $66.9 \%$ for
November-February 2019-2020. The bars of $\mathrm{PM}_{2.5}$ and $\mathrm{PM}_{10}$ concentrations at $50-100 \mu \mathrm{g} \mathrm{m}^{-3}$ and $100-150 \mu \mathrm{g} \mathrm{m}^{-3}$ were sharp during the 2019-2020 winter compared with the previous five years. For $\mathrm{PM}_{10}$, the occurrence frequencies of the concentration below $150 \mu^{-3} \mathrm{~m}^{-3}$ for the previous five years constituted 52-58\%. For November-February 20192020, the most prominent occurrence frequency $(93.4 \%)$ of $\mathrm{PM}_{2.5}$ concentration was in the range between $0 \mu \mathrm{g} \mathrm{m}^{-3}$ and $150 \mu \mathrm{g} \mathrm{m}^{-3}$, and $\mathrm{PM}_{10}$ concentrations below $150 \mu \mathrm{g} \mathrm{m}^{-3}$ occurred more frequently ( $82.6 \%$ of the total cases).

Decreases in PM pollution after implementing a series of actions related to the ban on coal consumption are also found in other cities. In Beijing, China, strict control measures, such as a ban of raw coal consumption and replacement of coal-burning heating with electric heating, effectively reduced $\mathrm{PM}_{2.5}$ concentrations during the 2008 Olympic Games (Lang et al., 2017). Emission reduction plans which includes the reduction of coal consumption for residential, industrial, and commercial sectors have successfully reduced the air pollutant concentrations since the 1990s in the Seoul metropolitan area (Kim and Lee, 2018). There is no academic study that reported the reduction in PM concentration in Ulaanbaatar, Mongolia. To the authors' knowledge, the current study reports for the first time the improvement in PM pollution in Ulaanbaatar.

\section{CONCLUSIONS}

This study shortly described the temporal variations in
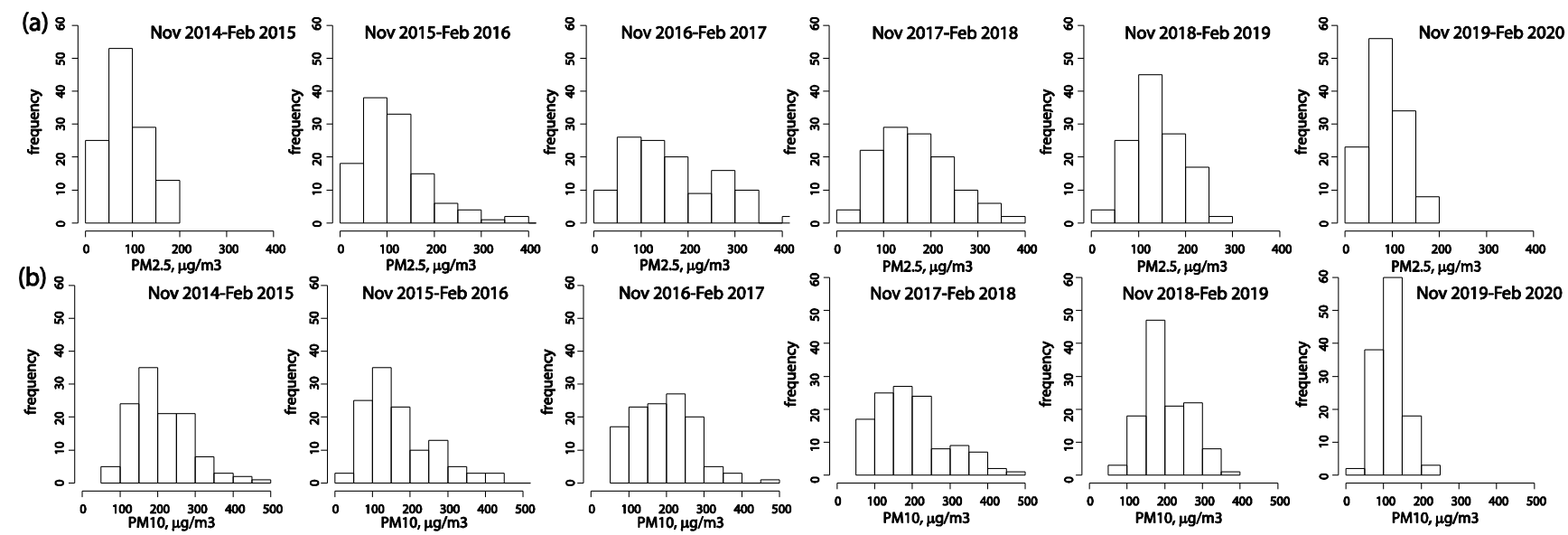

Fig. 5. Frequency distribution histograms of (a) $\mathrm{PM}_{2.5}$ and (b) $\mathrm{PM}_{10}$ for November-February in 2014-2015, 2015-2016, 2016-2017, 2017-2018, 2018-2019, and 2019-2020. 
PM concentrations in Ulaanbaatar, Mongolia, for January 2014-February 2020. Pronounced seasonal and diurnal patterns were found for $\mathrm{PM}_{2.5}$ and $\mathrm{PM}_{10}$ concentrations. The concentrations were the highest in cold months. Bimodal daily peaks of PM concentrations were observed.

The $\mathrm{PM}_{2.5}$ and $\mathrm{PM}_{10}$ concentrations in the ambient air of Ulaanbaatar during the 2019-2020 winter were different than those of the previous winters. The data obtained from the national air quality monitoring network showed large and significant reductions of $46 \%$ and $55 \%$ in the maximum $\mathrm{PM}_{2.5}$ and $\mathrm{PM}_{10}$ concentrations in Ulaanbaatar, respectively. It became evident that the number of heavily polluted days was substantially reduced during the 2019-2020 winter compared to the winters of the previous five years.

This study proposes several directions for further research. Pollution source apportionment and emission inventories will hopefully change in accordance with the replacement of raw coal by briquette fuel. The modified emission inventory can be used in future forecasting and modeling works. Studies on relevant benefits from the improvement in air quality are expected to be considered. Additionally, highresolution spatial variations in air pollution should be investigated to suggest air pollution reduction measures. Although PM concentration levels were reduced as a result of resources, due to an enormous investment of time, and will, but still far exceed international recommendations, and further air quality improvement may occur after taking a set of multiple actions with accurate planning management.

\section{ACKNOWLEDGMENTS}

The authors appreciate two anonymous reviewers for their detailed and helpful comments on the manuscript. This research was performed with the financial support of the National University of Mongolia (P2018-3607), the TWAS foundation (18-164 RG/CHE/AS_G), and the Science Technological Foundation, Mongolia (RUS/2019/14).

\section{REFERENCES}

Adame, J.A., Hernandez-Ceballos, M.A., Sorribas, M., Lozano, A. and De la Morena, B.A. (2014). Weekendweekday effect assessment for $\mathrm{O}_{3}, \mathrm{NO}_{\mathrm{x}}, \mathrm{CO}$, and $\mathrm{PM}_{10}$ in Andalusia, Spain (2003-2008). Aerosol Air Qual. Res. 14: 1862-1874. https://doi.org/10.4209/aaqr.2014.02.0026

Allen, R.W., Gombojav, E., Barkhasragchaa, B., Tsogtbaatar, B., Lkhasuren, O., Amram, O., Takaro, T.K. and Janes, C.R. (2013). An assessment of air pollution and its attributable mortality in Ulaanbaatar, Mongolia. Air Qual. Atmos. Health 6: 137-150. https://doi.org/10.1007/s1186 9-011-0154-3

Davy, P.K., Gunchin G., Markwitz A., Trompetter W.J., Barry, B.J., Shagjjamba, D. and Lodoysamba, S. (2011). Air particulate matter pollution in Ulaanbaatar, Mongolia: Determination of composition, source contributions and source locations. Atmos. Pollut. Res. 6: 126-137. https://doi.org/10.5094/APR.2011.017

Enkhjargal, A. and Burmaajav, B. (2015). Impact of the ambient air $\mathrm{PM}_{2.5}$ on cardiovascular diseases of
Ulaanbaatar residents. Geogr. Environ. Sustainability 8: 35-41. https://doi.org/10.24057/2071-9388-2015-8-4-3541

Enkhmaa, D., Warburton, N., Javzandulam, B., Uyanga, J., Khishigsuren, Y., Lodoysamba, S., Enkhtur, S. and Warburton, D. (2014). Seasonal ambient air pollution correlates strongly with spontaneous abortion in Mongolia. BMC Pregnancy Childbirth 14: 146. https://doi.org/10.1186/1471-2393-14-146

Ganbat, G. and Baik, J.J. (2016). Wintertime winds in and around the Ulaanbaatar metropolitan area in the presence of a temperature inversion. Asia-Pac. J. Atmos. Sci. 52: 309-325. https://doi.org/10.1007/s13143-016-0007-y

Guttikunda, S.K. (2007). Urban air pollution analysis for Ulaanbaatar, Mongolia. Consultation report. The World Bank, Washington, DC.

Guttikunda, S.K., Lodoysamba, S., Bulgansaikhan, B. and Dashdondog, B. (2013). Particulate pollution in Ulaanbaatar, Mongolia. Air Qual. Atmos. Health 6: 589-601. https://doi.org/10.1007/s11869-013-0198-7

Hopke, P.K., Cohen, D.D., Begum, B.A., Biswas, S.K., Ni, B., Pandit, G.G., Santoso, M., Chung, Y.S., Davy, P., Markwitz, A., Waheed, S., Siddique, N., Santos, F.L., Pabroa, P.C.B., Seneviratne, M.C.S., Wimolwattanapun, W., Bunprapob, S., Vuong, T.B., Duy Hien, P. and Markowicz, A. (2008). Urban air quality in the Asian region. Sci. Total Environ. 404: 103-112. https://doi.org/ 10.1016/j.scitotenv.2008.05.039

Kim, J.W., Han, B.S. and Baik, J.J. (2020). Temporal and spatial variations of workday-holiday particulate matter concentration differences in Seoul. J. Korean Soc. Atmos. Environ. 36: 25-30. https://doi.org/10.5572/KOSAE.202 0.36 .1 .025

Kim, Y.L. and Lee, G. (2018). Trend of air quality in Seoul: Policy and science. Aerosol Air Qual. Res. 18: 21412156. https://doi.org/10.4209/aaqr.2018.03.0081

Lang, J., Zhang, Y., Zhou, Y., Cheng, S., Chen, D., Guo, X., Chen, S., Li, X., Xing, X. and Wang, H. (2017). Trends of $\mathrm{PM}_{2.5}$ and Chemical Composition in Beijing, 20002015. Aerosol Air Qual. Res. 17: 412-425. https://doi.org/ 10.4209/aaqr.2016.07.0307

Lim, C.C., Thurston, G.D., Shamy, M., Alghamdi, M., Khoder, M., Mohorjy, A.M., Alkhalaf, A.K., Brocato, J., Chen, L.C. and Costa, M. (2018). Temporal variations of fine and coarse particulate matter sources in Jeddah, Saudi Arabia. J. Air Waste Manage. Assoc. 68: 123-138. https://doi.org/10.1080/10962247.2017.1344158

Liu, Z., Hu, B., Wang, L., Wu, F., Gao, W. and Wang, Y. (2014). Seasonal and diurnal variation in particulate matter $\left(\mathrm{PM}_{10}\right.$ and $\left.\mathrm{PM}_{2.5}\right)$ at an urban site of Beijing: Analyses from a 9-year study. Environ. Sci. Pollut. Res. 22: 627-642. https://doi.org/10.1007/s11356-014-3347-0

Mongolian Statistical Information Service (2020). www.1212.mn

National Audit Report (2018). National Audit Report. https://archive.audit.mn/wp-content/uploads/2018/10/tse wer-agaar-san.pdf

Wang, M., Kai, K., Sugimoto, N. and Enkhmaa, S. (2018). Meteorological factors affecting winter particulate air 
pollution in Ulaanbaatar from 2008 to 2016. Asian $J$ Atmos. Environ. 12: 244-254. https://doi.org/10.5572/aja e.2018.12.3.244
Received for review, April 24, 2020

Revised, August 12, 2020

Accepted, August 13, 2020 